The Review of Finance and Banking

print ISSN 2067-2713, online ISSN 2067-3825

Volume 12, Issue 1, Year 2020

http://dx.doi.org/10.24818/rfb.20.12.01.05, Pages $63-78$

\title{
ASYMMETRIC IMPACTS OF OIL PRICE SHOCKS ON UNEMPLOYMENT: EVIDENCE FROM NIGERIA
}

\author{
ANTHONY ENISAN AKINLO
}

\begin{abstract}
Nigerian economy depends mainly on oil. The country produces and exports crude oil and at the same time, imports refined oil as input into domestic production. Consequently, changes in oil price will have a major effect on phenomenon such as unemployment rate. This paper assesses the impacts of changes in oil price on the unemployment rate. Applying the standard linear Autoregressive Distributed Lag (ARDL) approach, the result shows that shock to oil price has no significant long-run effect on the rate of unemployment. However, when the non-linear ARDL (NARDL) is applied, the results provide evidence of log-run but asymmetric effects of oil price shocks on the rate of unemployment. This finding suggests that the best way of modelling the unemployment-oil price nexus is NARDL that allows for short-run symmetry with long-run asymmetry.
\end{abstract}

\section{INTRODUCTION}

Studies on the way movement in oil price impacts unemployment are very scarce in Nigeria. Essentially, lack of studies on this subject matter can be ascribed to two main factors. Firstly, before the 1980s, Nigeria was a major oil exporter, and the government realized a huge amount of revenue from oil because the international price of the commodity increased massively. Secondly, the rate of unemployment in the country was extremely low in the 60s and 70s. However, since the beginning of 1980, the trend has changed significantly. Nigeria though remains a major crude oil producer and exporter becomes a major importer of refined oil products. This development is the one the effects of the collapse of domestic oil refineries and high level of corruption that characterizes the oil sub -sector of the Nigerian economy.

Asides, the abundance of oil coupled with the neglect of other sources of energy including coal, electricity and gas, have made the country to depend mainly on petroleum to energize economic activity. Hence, petroleum constitutes a significant input component for production in many sectors, including agriculture, manufacturing, construction, transportation, and services. Given the fact that oil is major input in production in Nigeria, changes in its price is likely to have a serious impact not only on the growth of the economy but also on the level of unemployment. In the same way, the rate of unemployment has increased phenomenally in the country since 1980. For example, the rate of unemployment in the country increased from 6.47 percentage point in 1980 to 13.1 percentage point in 2000. The percentage rose further to 28.5 in 2013. The high and increasing rate of unemployment in the country coupled with the high volatility of oil price has brought to the front burner debate on the impacts of the latter on the former. In the literature, this debate is popularly referred to as unemployment-oil shocks nexus.

Many theoretical and empirical studies have examined the unemployment-oil price nexus. However, no consensus has emerged as to the nature of the relationship between movements

Received by the editors May 3, 2020. Accepted by the editors June 12, 2020.

Keywords: unemployment; oil price; asymmetry effects; nonlinear ARDL; Nigeria.

JEL Classification: C32; E24; Q43.

Anthony Enisan Akinlo, PhD, Professor, Department of Economics, Obafemi Awolowo University, Ile-Ife, Nigeria. E-mail: aakinlo@oauife.edu.ng.

This paper is in final form and no version of it will be submitted for publication elsewhere. 
in oil prices and unemployment. As an illustration, studies from Schmidt and Zimmermann (2005, 2007), and Cuetas and Gil-Alana (2018) report that the impact of changes in oil prices on unemployment is minimal; while Ewing and Thompson (2007) and Papapetrou (2001) report the significant detrimental effect of oil price shocks on the level of employment. The studies by Senzangakhona and Choga (2015) and Loschel and Oberndorfer (2017) reveal significant adverse effects of oil price changes on unemployment in Turkey, South Africa, and Germany. A similar finding was reported by Ahmad (2013) for Pakistan.

Despite the relevance and importance of the topic, there is a dearth of empirical literature on the impacts of changes in oil price on unemployment in Nigeria. This gap in the literature provides the motivation for this paper: we aim at examining the impacts of oil price movements on the rates of unemployment Nigeria. We do this by distinguishing between the effects of negative and positive components of oil price changes in unemployment. The essence of decomposing movements in oil prices into negative and positive parts is to see if unemployment reacts differently to a decline in oil price as compared to a rise. Primarily, the study will help us ascertain whether the interactions between oil price changes and unemployment differ for countries that are both crude oil exporter and at the same time major petroleum products importer as in the case of Nigeria.

The remainder of this article is divided into sections as follows: Section 2 provides an overview of oil price and unemployment in Nigeria. Section 3 gives a brief summary of theoretical and empirical literature on the oil price-unemployment nexus. Section 4 provides the methodology, which includes model specification, estimation and description of the data. Empirical results are presented in Section 5. Section 6 provides the conclusion.

\section{Overview Oil price and unemployment in Nigeria}

The path of the rate of unemployment and oil prices over the study period is shown in figure 1. Crude oil price was US $\$ 35.52 / \mathrm{b}$ in 1980 dropped steadily to US $\$ 13.53 / \mathrm{b}$ in 1986 . The fall in the price of oil in the early years of 1980 was the result of the conclusion of the Iranian revolution in 1989 and the Iran-Iraq war in 1981. The crude oil price increased slightly to US $\$ 17.72 / \mathrm{b}$ in 1987; dropped to US $\$ 14.24 / \mathrm{b}$ in 1988 but reached a peak of US $\$ 22.76 / \mathrm{b}$ in 1990 . The spike in oil prices in 1990 could be attributed largely to Iraqi invasion of Kuwait which knocked out two of the world's biggest oil producers. However, oil prices maintained a downward trend until 1996 when it peaked at US $\$ 20.29 / \mathrm{b}$. Major oil price increase started from 2000 when it was US $\$ 27.6 / \mathrm{b}$ but increased consistently to reach US $\$ 109.45 / \mathrm{b}$ and US $\$ 105.87 / \mathrm{b}$ in 2013 and 2015 respectively. This phenomenal increase in oil price could be attributed to increase in oil demand by the newly industrialized countries following the unprecedented economic growth of these economies. The second reason was the slowdown in oil supply growth. However, the price of oil declined sharply to US $\$ 49.49 / \mathrm{b}$ and US $\$ 40.68 / \mathrm{b}$ in 2015 and 2016 . The sharp decline in the prices of oil during this period could be attributed to increase oil supply by some non OPEC members.

On the other hand, unemployment rate remained consistently around $6 \%$ for the period 1980-1987. Indeed, the percentage dropped to around 3.4 per cent between 1990 and 1999. The decrease in unemployment rate between 1990 and 1998 can be attributed to various poverty alleviation programmes implemented by the government to address to address unemployment in Nigeria. The National Directorate Employment (NDE) introduced several measures to reduce the address the high level of employment. However, the rate of unemployment turned double digits 13.1 per cent as from year 2000. The percentage increased to 28.5 per cent in 2013 . The increase in the rate of unemployment from the year 2000 was a result the downturn in the Nigerian country and the collapse of the manufacturing sector. The rate of unemployment declined to single digit in 2014 and 2015. In general, causal observation of figure 1 shows that between 1980-1985 when oil price was falling, unemployment rate was relatively constant; however when crude oil price dropped precipitously between 1989-1999, unemployment rate equally dropped. In the same way, when crude oil price increased from 2000 to 2013; the 
unemployment rate increased significantly over the same period. Hence, the determination of the exact nature of the relationship between crude oil price and unemployment becomes an empirical issue.

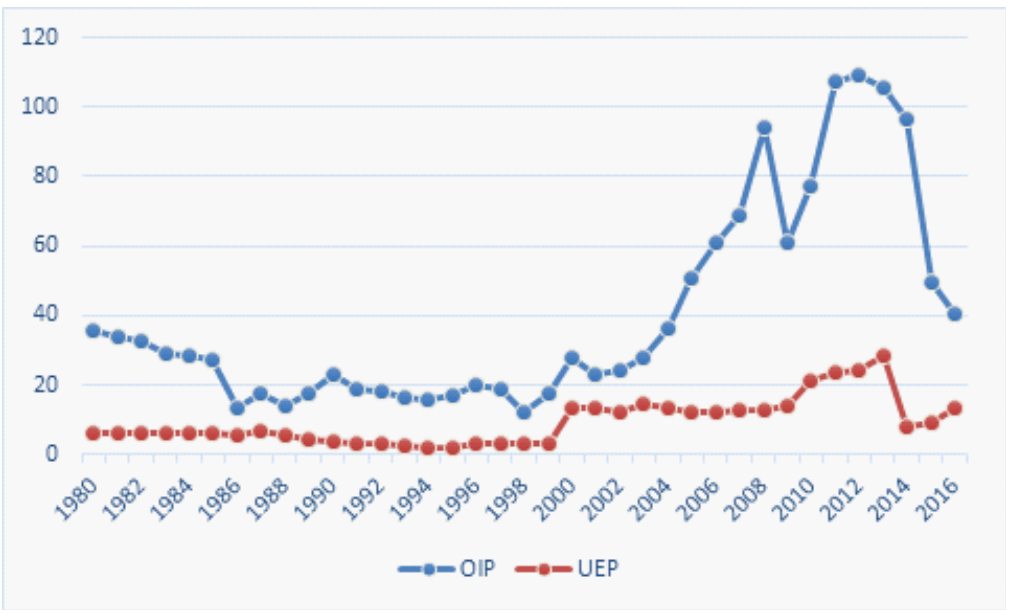

\section{Theoretical and Empirical Issues}

3.1. Theoretical Literature. Several studies have discussed theoretically and empirically the various channels through which oil price fluctuations can affect unemployment. The channels include increased production costs that arises from increased oil prices (Brown and Yucel 1999, 2002), reduced purchasing power due to increased oil prices (Dohner, 1981), and increased money demand caused by rising oil price which may lead to increased interest rate with an adverse effect production and employment (Monk, 1994). Other channels are inflation-induced tight monetary policies that are associated with increased oil price and finally, labour and capital reallocation across sectors by firms that comes from increased oil prices with possible adverse effect on employment (Loungani, 1986).

However, the extent to which oil price changes affect economic activity and unemployment depends on many factors. These include the extent to which the country depends on oil and the degree of substitution between oil and other inputs in the production process. Undoubtedly, for countries like Nigeria that depend mainly on oil as a source revenue and production, oil price fluctuations will have significant effect on economic activity and thus unemployment rate.

3.2. Empirical evidence. Many empirical studies have been provided on the effect oil price changes on unemployment. Some of these studies reported that rising oil prices by altering production and generating uncertainty, led to delayed investment, low production and high unemployment (Altay, Ebru and Mert, 2013 and Uenzangakhona and Chong, 2015). In the same way, the studies by Lescaroux and Mignon (2008) reported that oil price Granger-caused unemployment in the long run. Hamilton (1983) found negative effect on oil price change on employment and this was supported by several other studies including Garruth, Hooker and Oswald (1998), and Michieka and Gearhart (2015). In addition, few empirical studies found that the relationship between oil prices and unemployment is asymmetrical. These studies include Bocklet and Baek (2018), Kisswani and Kisswani (2019). The summary of existing empirical studies on oil price-unemployment is provided in Table 1. The general observation from table 1 is that most existing studies are focused on developed and industrialized countries. Only few studies have been done on the subject matter in the developing countries like Nigeria. There is therefore the need to fill this gap in the literature. 


\begin{tabular}{|c|c|c|c|c|c|c|}
\hline $\mathrm{S} / \mathrm{N}$ & Author & Period & Country & Variables & Methodology & Findings \\
\hline 1 & $\begin{array}{l}\text { Hamilton } \\
(1983)\end{array}$ & $1949-1980$ & USA & $\begin{array}{l}\text { Unemployment rate, } \\
\text { oil price, real GNP, } \\
\text { money supply, implicit } \\
\text { price deflator and } \\
\text { hourly compensation } \\
\text { per worker }\end{array}$ & $\begin{array}{l}\text { Granger- } \\
\text { Causality and } \\
\text { OLS regression }\end{array}$ & $\begin{array}{l}\text { Strong link between oil } \\
\text { prices and unemploy- } \\
\text { ment rate }\end{array}$ \\
\hline 2 & $\begin{array}{l}\text { Loungani } \\
(1986)\end{array}$ & $1947-1982$ & $\begin{array}{l}28 \text { USA in- } \\
\text { dustries }\end{array}$ & $\begin{array}{l}\text { Employment rate, oil } \\
\text { price }\end{array}$ & $\begin{array}{l}\text { Dispersion } \\
\text { Index }\end{array}$ & $\begin{array}{l}\text { Oil price leads to } \\
\text { higher unemployment }\end{array}$ \\
\hline 3 & $\begin{array}{l}\text { Gisser and } \\
\text { Goodwin } \\
(1985)\end{array}$ & $1948-1980$ & USA & $\begin{array}{l}\text { Oil price, unem- } \\
\text { ployment rate, GDP } \\
\text { growth, inflation } \\
\text { manufacturing output }\end{array}$ & OLS & $\begin{array}{l}\text { No significant correla- } \\
\text { tion between oil price } \\
\text { change and unemploy- } \\
\text { ment }\end{array}$ \\
\hline 4 & $\begin{array}{l}\text { Hamilton } \\
(1988)\end{array}$ & $\begin{array}{l}1948: 1- \\
1988: 2\end{array}$ & USA & $\begin{array}{l}\text { Oil price, unemploy- } \\
\text { ment }\end{array}$ & $\begin{array}{l}\text { Multi-sectoral } \\
\text { model }\end{array}$ & $\begin{array}{l}\text { Marginal significant } \\
\text { correlation of oil price } \\
\text { with unemployment } \\
\text { and evidence of } \\
\text { asymmetric effect. }\end{array}$ \\
\hline 5 & Mory (1993) & 1951-1990 & USA & $\begin{array}{l}\text { Oil price, } \\
\text { growth, } \\
\text { facturing } \\
\text { unemployment }\end{array}$ & OLS & $\begin{array}{l}\text { Asymmetric effect of } \\
\text { oil price change on un- } \\
\text { employment }\end{array}$ \\
\hline 6 & $\begin{array}{l}\text { Lee et al } \\
(1995)\end{array}$ & 1949-1992 & USA & $\begin{array}{l}\text { Oil price, unemploy- } \\
\text { ment, GNP growth }\end{array}$ & $\begin{array}{l}\text { VAR, GARCH } \\
\text { model }\end{array}$ & $\begin{array}{l}\text { Significant relation- } \\
\text { ship between oil } \\
\text { price change with } \\
\text { unemployment and } \\
\text { GNP growth }\end{array}$ \\
\hline 7 & Uri (1996) & $1947-1995$ & USA & $\begin{array}{l}\text { Crude oil price, unem- } \\
\text { ployment rate }\end{array}$ & $\begin{array}{l}\text { Granger- } \\
\text { causality }\end{array}$ & $\begin{array}{l}\text { Significant } \\
\text { lation between } \\
\text { price change on } \\
\text { unemployment and } \\
\text { output }\end{array}$ \\
\hline 8 & $\begin{array}{l}\text { Garruth et al } \\
\text { (1998) }\end{array}$ & $\begin{array}{l}1954: 2- \\
1995: 2\end{array}$ & USA & $\begin{array}{l}\text { Real oil price, inter- } \\
\text { est rate, and unem- } \\
\text { ployment rate }\end{array}$ & $\begin{array}{l}\text { Granger- } \\
\text { Causality, } \\
\text { ECM }\end{array}$ & $\begin{array}{l}\text { Long run relationship } \\
\text { between unemploy- } \\
\text { ment rate, interest } \\
\text { rate and oil price. }\end{array}$ \\
\hline 9 & $\begin{array}{l}\text { Papapetrou } \\
(2001)\end{array}$ & $\begin{array}{l}1989: 1- \\
1996: 6\end{array}$ & Greece & $\begin{array}{l}\text { Unemployment rate, } \\
\text { oil price, employment } \\
\text { rate and GDP growth }\end{array}$ & VAR & $\begin{array}{l}\text { Negative relation be- } \\
\text { tween oil price change } \\
\text { and unemployment }\end{array}$ \\
\hline 10 & $\begin{array}{l}\text { Ewing and } \\
\text { Thompson } \\
(2007)\end{array}$ & $1990-2005$ & USA & $\begin{array}{l}\text { Real effective ex- } \\
\text { change rate, oil price, } \\
\text { employment }\end{array}$ & $\begin{array}{l}\text { Cointegration } \\
\text { and error } \\
\text { correction } \\
\text { model }\end{array}$ & $\begin{array}{l}\text { Negative significant } \\
\text { correlation of oil } \\
\text { price change with } \\
\text { unemployment }\end{array}$ \\
\hline
\end{tabular}




\begin{tabular}{|c|c|c|c|c|c|c|}
\hline $\mathrm{S} / \mathrm{N}$ & Author & Period & Country & Variables & Methodology & Findings \\
\hline 11 & $\begin{array}{l}\text { Robalo and } \\
\text { Salvada } \\
(2008)\end{array}$ & 1968-2005 & Portugal & $\begin{array}{l}\text { Oil price, unemploy- } \\
\text { ment rate, real GDP, } \\
\text { IPI, total employment } \\
\text { and inflation }\end{array}$ & VAR & $\begin{array}{l}\text { Oil price change } \\
\text { has significant effect } \\
\text { on unemployment } \\
\text { over the interval } \\
\text { 1968-1995. }\end{array}$ \\
\hline 12 & $\begin{array}{l}\text { Andreopoulos } \\
(2008)\end{array}$ & $\begin{array}{l}1953: 2- \\
1996: 2\end{array}$ & USA & $\begin{array}{l}\text { Unemployment rate, } \\
\text { interest rate and oil } \\
\text { price }\end{array}$ & $\begin{array}{l}\text { Markov- } \\
\text { Switching Auto } \\
\text { Regression } \\
\text { (VAR). }\end{array}$ & $\begin{array}{l}\text { Real oil price has pre- } \\
\text { dicting power only in } \\
\text { the long run, while } \\
\text { real interest rate has } \\
\text { predicting power only } \\
\text { in the expansion time }\end{array}$ \\
\hline 13 & $\begin{array}{l}\text { Rafiq et al. } \\
(2009)\end{array}$ & $\begin{array}{l}1993: 1- \\
2006: 4\end{array}$ & Thailand & $\begin{array}{l}\text { GDP growth, invest- } \\
\text { ment, trade balance, } \\
\text { interest rate, unem- } \\
\text { ployment rate, infla- } \\
\text { tion, budget deficit }\end{array}$ & VAR & $\begin{array}{l}\text { Oil price volatility has } \\
\text { significant impact on } \\
\text { unemployment rate } \\
\text { and investment }\end{array}$ \\
\hline 14 & $\begin{array}{l}\text { Loschel and } \\
\text { Oberndorfer } \\
(2009)\end{array}$ & $\begin{array}{l}\text { 1973: M10- } \\
\text { 2008:M1 }\end{array}$ & Germany & $\begin{array}{l}\text { Unemployment rate, } \\
\text { industrial production, } \\
\text { interest rate, inflation } \\
\text { and oil price }\end{array}$ & VAR & $\begin{array}{l}\text { Oil price increases in- } \\
\text { duce a rise in unem- } \\
\text { ployment rate }\end{array}$ \\
\hline 15 & $\begin{array}{l}\text { Dogrul and } \\
\text { Soytas (2010) }\end{array}$ & $\begin{array}{l}2005: 1- \\
2009: 8\end{array}$ & Turkey & $\begin{array}{l}\text { Unemployment rate, } \\
\text { crude oil price and } \\
\text { interest rate }\end{array}$ & $\begin{array}{l}\text { Toda- } \\
\text { Yamamoto }\end{array}$ & $\begin{array}{l}\text { Real price of oil im- } \\
\text { prove the forecast of } \\
\text { unemployment in the } \\
\text { long run. }\end{array}$ \\
\hline 16 & $\begin{array}{l}\text { Gunu abd } \\
\text { Kilishi }(2010)\end{array}$ & $1970-2008$ & Nigeria & $\begin{array}{l}\text { Oil price, real GDP, } \\
\text { unemployment rate, } \\
\text { money supply and } \\
\text { consumer price index }\end{array}$ & VAR & $\begin{array}{l}\text { Oil price have sig- } \\
\text { nificant impact on } \\
\text { unemployment, GDP } \\
\text { growth and money } \\
\text { supply }\end{array}$ \\
\hline 17 & $\begin{array}{c}\text { Ran and } \\
\text { Voon }(2012)\end{array}$ & $\begin{array}{l}1984: 1- \\
2007: 3\end{array}$ & $\begin{array}{l}\text { Hong Kong, } \\
\text { Singapore, } \\
\text { South Korea } \\
\text { and Taiwan }\end{array}$ & $\begin{array}{l}\text { Real GDP, unemploy- } \\
\text { ment rate, price level, } \\
\text { import price, interest } \\
\text { rate, oil price and oil } \\
\text { import }\end{array}$ & $\mathrm{VAR} / \mathrm{VECM}$ & $\begin{array}{l}\text { Significant impact of } \\
\text { oil price shocks on } \\
\text { macroeconomic vari- } \\
\text { ables and significant } \\
\text { positive impact of } \\
\text { oil price shocks on } \\
\text { unemployment after } \\
\text { three time lags. }\end{array}$ \\
\hline 18 & $\begin{array}{l}\text { Ahmad } \\
(2013)\end{array}$ & $\begin{array}{l}\text { 1991: M01- } \\
\text { 2010:M } 12\end{array}$ & Pakistan & $\begin{array}{l}\text { Oil price, unemploy- } \\
\text { ment rate, GDP defla- } \\
\text { tor and Treasury bill } \\
\text { rate }\end{array}$ & $\begin{array}{l}\text { Toda- } \\
\text { Yamamoto } \\
\text { and Causality }\end{array}$ & $\begin{array}{l}\text { Oil price change } s \\
\text { have significant effect } \\
\text { on unemployment } \\
\text { rate. Oil prices can } \\
\text { be used to improve } \\
\text { the forecasting unem- } \\
\text { ployment in the long } \\
\text { run }\end{array}$ \\
\hline
\end{tabular}




\begin{tabular}{|c|c|c|c|c|c|c|}
\hline $\mathrm{S} / \mathrm{N}$ & Author & Period & Country & Variables & Methodology & Findings \\
\hline 19 & $\begin{array}{l}\text { Altay et al. } \\
(2013)\end{array}$ & $\begin{array}{l}2000: 1- \\
2012: 4\end{array}$ & Turkey & $\begin{array}{l}\text { Oil price, GDP growth } \\
\text { and employment }\end{array}$ & $\mathrm{VECM}$ & $\begin{array}{l}\text { In the short run, } \\
\text { unidirectional causal- } \\
\text { ity from oil price } \\
\text { to employment. In } \\
\text { the long run, oil } \\
\text { price do not cause } \\
\text { employment. }\end{array}$ \\
\hline 20 & $\begin{array}{l}\text { Senzangakhona } \\
\text { and Choga } \\
(2015)\end{array}$ & $\begin{array}{l}1990: 1- \\
2010: 4\end{array}$ & South Africa & $\begin{array}{l}\text { Crude oil price, real } \\
\text { interest rate, real ef- } \\
\text { fective exchange rate } \\
\text { and real GDP }\end{array}$ & $\begin{array}{l}\text { Johansen coin- } \\
\text { tegration based } \\
\text { on VAR }\end{array}$ & $\begin{array}{l}\text { Crude oil prices are } \\
\text { positively related to } \\
\text { unemployment in the } \\
\text { long run. The oppo- } \\
\text { site holds in the short } \\
\text { run. }\end{array}$ \\
\hline 21 & $\begin{array}{l}\text { Cuestas and } \\
\text { Gil-Alana } \\
(2018)\end{array}$ & $\begin{array}{l}2000: 1- \\
2015: 4\end{array}$ & $\begin{array}{l}8 \text { European } \\
\text { countries }\end{array}$ & $\begin{array}{l}\text { Unemployment rates } \\
\text { and oil price }\end{array}$ & $\begin{array}{l}\text { ARDL bound } \\
\text { tests and } \\
\text { nonlinear }\end{array}$ & $\begin{array}{l}\text { Positive oil price } \\
\text { shocks reduce the un- } \\
\text { employment rate and } \\
\text { negative shocks tend } \\
\text { to raise unemployment } \\
\text { rate. }\end{array}$ \\
\hline 22 & $\begin{array}{l}\text { Bocklet and } \\
\text { Baek (2018) }\end{array}$ & $\begin{array}{l}1987: 3- \\
2014: 4\end{array}$ & A laska & $\begin{array}{l}\text { Unemployment rate, } \\
\text { oil price, income and } \\
\text { interest rate }\end{array}$ & $\begin{array}{l}\text { Nonlinear } \\
\text { ARDL }\end{array}$ & $\begin{array}{l}\text { Changes in oil prices } \\
\text { have asymmetric } \\
\text { effects on unemploy- } \\
\text { ment rate in the short } \\
\text { run. }\end{array}$ \\
\hline 23 & $\begin{array}{l}\text { Kisswani and } \\
\text { Kisswani } \\
(2019)\end{array}$ & $1970-2015$ & USA & $\begin{array}{l}\text { Total employment, } \\
\text { male employment, } \\
\text { female employment } \\
\text { and oil price }\end{array}$ & $\begin{array}{l}\text { ARDL, non- } \\
\text { linear ARDL } \\
\text { and Granger- } \\
\text { Causality }\end{array}$ & $\begin{array}{l}\text { Asymmetric effect of } \\
\text { oil price change on } \\
\text { employment (male and } \\
\text { female) in the long } \\
\text { run and short run. } \\
\text { Unidirectional causal- } \\
\text { ity from oil price de- } \\
\text { crease to both total } \\
\text { employment and male } \\
\text { employment. }\end{array}$ \\
\hline 24 & $\begin{array}{l}\text { Kocaarslan } \\
\text { et al. (2019) }\end{array}$ & $\begin{array}{l}\text { 2007: } \\
\text { M5-2019: M } 4\end{array}$ & USA & $\begin{array}{lr}\text { Oil prices, inter- } \\
\text { est rate, oil price } \\
\text { uncertainty } & \text { and } \\
\text { unemployment } & \end{array}$ & $\begin{array}{l}\text { Nonlinear } \\
\text { ARDL }\end{array}$ & $\begin{array}{l}\text { An increased in oil } \\
\text { price leads to an in- } \\
\text { crease unemployment } \\
\text { while there is no sig- } \\
\text { nificant impact of re- } \\
\text { duced oil prices }\end{array}$ \\
\hline
\end{tabular}

\section{Methodology}

4.1. Model Specification. To examine the impacts of oil price movements on unemployment, we adopt the th eoretical framework popularised by Shapiro and Stiglitz (1984). This framework is called efficiency-wage model. The wage equation stated in its most simple form is given as:

$$
W A=f(U E B, U E P)
$$

where WA denotes the wage rate, $U E B$ represents the unemployment benefits' level, and $U E P$ represents the rate of unemployment. We assume three inputs, namely capital $(K)$, labour $(L)$, and energy input denoted as $(O I)$. Furthermore, these three inputs are utilized in 
the production of a single output level sold at a price indicated as $\mathrm{P}$. Thus, the unit minimum cost function is given as:

$$
C=\frac{1}{\pi} \varphi(W A, R P, O I P)
$$

where $\pi$ is the measurement for neutral technical progress; $R P$ is the rental price (proxy by interest rate); and $O I P$ is the market price of oil. At equilibrium in a perfect competitive market, profit becomes zero $(P-C=0)$. As equation 2 is homogenous of degree one, price $(P)$ can be equated to unity without loss of generality (Bocklet and Baek 2017). Consequently, equation 2 in the real prices can be written thus:

$$
\pi=\varphi(W A, R P, O I P)
$$

where $\pi$ is expected to increase as the economic activity grows. By substituting out wage $(W A)$ and combining equations 1 and 3 we obtain:

$$
U E P=\gamma(O I P, R P, U E B(\pi))
$$

In Nigeria, there is no unemployment benefits scheme, as such, we proxy it by real gross domestic product. This proxy is valid based on the proposition and empirical finding that economic growth is a major determinant of real unemployment benefits (Bocklet and Baek 2017). In the same way, the rental price is measure as the interest rate. However, as the interest rate was relatively constant over the study period in Nigeria coupled with the fact that several studies have shown that interest rate is a not a major determinant of unemployment (see for example, Moller 2013, 2017, Cuestas and Gil-Alana, 2017), we replace it with inflow of foreign direct investment (FDI). The purpose of incorporating FDI is to test the assertion that foreign direct investments do not lead to employment, particularly where they are concentrated in the oil sector as in the case of Nigeria.

Hence, our basic equation for assessing the impact of oil price movements on unemployment in Nigeria is given as:

$$
\ln U E P_{t}=\alpha_{0}+\alpha_{1} \ln O I P_{t}+\alpha_{2} \ln R G D P_{t}+\alpha_{3} \ln F D I_{t}+\mu_{t}
$$

where $U E P_{t}$ is the unemployment rate, $O I P_{t}$ is the crude oil price; $R G D P_{t}$ represents the real gross domestic product, $F D I_{t}$ is foreign direct investments; and $\mu_{t}$ is the error term and it measures the effects of other causes of unemployment.

4.2. Estimation Methods. In the literature, the error-correction (ECM) methodology is the commonly utilized approach to analyze the relationship between variables which are I(1) i.e. integrated of order one. However, where variables in the model have different order $\mathrm{I}(0)$ and I(1), ECM approach becomes invalid. Hence, Pesaran, Shin and Smith (2001) developed a linear autoregressive distributed lag model (ARDL) to address this problem. The ARDL (p, q) bounds test for co-integration in its general form is given as:

$$
\Delta y_{t}=\alpha_{0}+\rho y_{t-1}+\theta x_{t-1}+\varphi \Psi_{t}+\sum_{i=1}^{p-1} \alpha_{i} \triangle y_{t-i}+\sum_{i=0}^{q-1} \delta_{i} \triangle x_{t-i}+\mu_{t}
$$

where $\Psi_{t}$ is a vector of deterministic variables; while $\mu_{t}$ is the stochastic process. In equation (6) if $\rho=\theta=0$, the two variables in $x_{t}$ and $y_{t}$ are not co-integrated. To ascertain the presence of co-integration amongst variables in a model, Pesaran et al. (2001) proposed the $F$-test. Generally, long run co-movement is confirmed between two variables $x_{t}$ and $y_{t}$ where the $F$-statistic is greater than the upper bound of the two critical bounds. However, where the calculated $F$-statistic is lower than lower bound of the two critical bounds, there is no cointegration between the two variables $x_{t}$ and $y_{t}$. In a situation where the $F$-statistics lies within the upper and lower bounds, it is indeterminate. Generally, the ARDL model as specified in equation (6) is based on the assumption of a linear combination of $x t$ and $y t$, which means 
a symmetric adjustment in the short and long run. However, in a situation where that the relationship between $x t$ and $y t$ is non- linear, and the impact of $x$ on $y$ is asymmetric, then equation (6) is said to be misspecified.

Shin, Yu and Greenwood-Nimmo (2014) amend equation (6) such that the probable asymmetric effects in both long and short run could be assessed. Basically, non-linear ARDL is generated from the linear ARDL by breaking $x t$ into two components, namely positive and negative partial sums as shown in equation (7):

where

$$
x_{t}=x_{0}+x_{t}^{+}+x_{t}^{-}
$$

$x_{t}^{+}=\sum_{i=1}^{t} \triangle x_{i}^{+}=\sum_{i=1}^{t} \max \left(\triangle x_{i}, 0\right)$ and $x_{t}^{-}=\sum_{i=1}^{t} \triangle x_{i}^{-}=\sum_{i=1}^{t} \min \left(\triangle x_{i}, 0\right)$.

In line with Shin, et al. (2014), the non-linear asymmetric co-integration regression is depicted thus:

$$
y_{t}=\beta^{+} x_{t}^{+}+\beta^{-} x_{t}^{-}+\mu_{t}
$$

Where $\beta^{+}$is the long-run coefficient that is associated with the positive change in $x_{t}$; while $\beta^{-}$is the long-run coefficient that is associated with negative change in $x_{t}$. According to Shin et al. (2014) by substituting equation (8) in the ARDL (p, q) model specified in equation (6), the derived non-linear asymmetric conditional ARDL (NARDL) is given as:

$$
\begin{aligned}
\triangle y_{t}= & \alpha_{0}+\rho y_{t-1}+\theta^{+} x_{t-1}^{+}+\theta^{-} x_{t-1}^{-}+\varphi \Psi_{t}+ \\
& +\sum_{i=1}^{p-1} \alpha_{i} \triangle y_{t-i}+\sum_{i=0}^{q-1}\left(\delta_{i}^{+} \triangle x_{t-i}^{+}+\delta_{i}^{-} \triangle x_{t-i}^{-}\right)+\mu_{t}
\end{aligned}
$$

where $\beta^{+}=-\theta^{+} / \rho$ and $\beta^{-}=-\theta^{-} / \rho$.

The implementation of the Shin et al. (2014) NARDL model entails listed steps: first, conduct of unit root test to ensure that no variable of order 2, i.e. I(2) is involved. This condition is important because the computed $F$-statistics for cointegration becomes invalid with the presence of an I(2) variable. Second, is the application of standard OLS to estimate equation (9). Third, ascertain the presence of long run co-movement between the levels of the series $y_{t}, x_{t}^{+}$and $x_{t}^{-}$using F-pss statistic proposed by Shin et al. (2014). This is referred to as the joint hypothesis of no cointegration $\left(\rho=\theta^{+}=\theta^{-}=0\right)$. Fourth, is the use of Wald test to test for the long-run and the short-run symmetry. The null hypothesis for long-run symmetry is stated as:

$\theta=\theta^{+}=\theta^{-}$. However, the null hypothesis for short-run symmetry can take either of the forms:

(1) $\delta_{i}^{+}=\delta_{i}^{-}$for all $\mathrm{i}=1,2, \ldots, \mathrm{q}$ or $(2) \sum_{i=0}^{q-1} \delta_{i}^{+} \quad=\sum_{i=0}^{q-1} \delta_{i}^{-}$.

4.3. Data. The data used to estimate the specified models are annual series for Nigeria. The series cover the period of 1980 to 2016. The data are sourced from the National Bureau of Statistics data base and Central Bank of Nigeria (CBN) Statistical Bulletin (2017) edition. Unemployment is defined as the rates of unemployment in Nigeria, oil price is logarithm of crude oil price; trade openness is measured logarithm of foreign direct investment (FDI) inflows into the country and real gross domestic product is obtained by deflating nominal gross domestic product with consumer price index. Table 2 shows the highlights of the descriptive statistics of the variables under consideration and the pair-wise correlations for the variables; while fig.1 shows the graphs of the variables used in the analysis ${ }^{1}$. The series are positively skewed showing that the distributions have long right tail. The series are leptokurtic (peaked) relative to normal except for FDI as their kurtosis values are greater than 3. Finally, Jacque-Bera statistic exceeds (in absolute value) the observed value and the probability generally low for all the series. The

\footnotetext{
${ }^{1}$ The data for analysis are available on request from the author.
} 
statistic indicates non-normal distribution of our time series. To reduce non-normality in the data for the analysis and ensure consistent findings, we use the logarithmic transformation of the series. The pair-wise correlation result shows that unemployment rate is positively correlated with oil price.

\begin{tabular}{ccccc}
\hline \multicolumn{5}{c}{ Table 2: Descriptive statistics and pair-wise correlations } \\
\hline Variables & RGDP & UEP & FDI & OIP \\
\hline Mean & 2058.213 & 9.400 & $4.99 \mathrm{E}+08$ & 40.212 \\
Median & 403.102 & 6.400 & $2.61 \mathrm{E}+08$ & 28.100 \\
Maximum & 11130.45 & 28.50 & $1.60 \mathrm{E}+09$ & 109.45 \\
Minimum & 4.201 & 1.800 & 861000.0 & 12.280 \\
Std. Dev. & 3131.123 & 6.761 & $5.25 \mathrm{E}+08$ & 29.772 \\
Skewness & 1.643 & 1.134 & 0.841 & 1.227 \\
Kurtosis & 4.690 & 3.692 & 2.329 & 3.193 \\
J. Bera & 21.047 & 8.671 & 5.059 & 9.338 \\
Probability & 0.0000027 & 0.0131 & 0.0797 & 0.00938 \\
Sum & 76153.9 & 374.800 & $1.85 \mathrm{E}+10$ & 1487.860 \\
Sum Squared & $3.53 \mathrm{E}+08$ & 1645.42 & $9.92 \mathrm{E}+18$ & 31909.18 \\
Observations & 37 & 37 & 37 & 37 \\
\hline Pair-wise correlation & & & & \\
\hline RGDP & 1 & & & \\
UEP & 0.566 & 1 & & \\
FDI & 0.412 & 0.951 & 0.836 & \\
OIP & 0.289 & 0.815 &
\end{tabular}
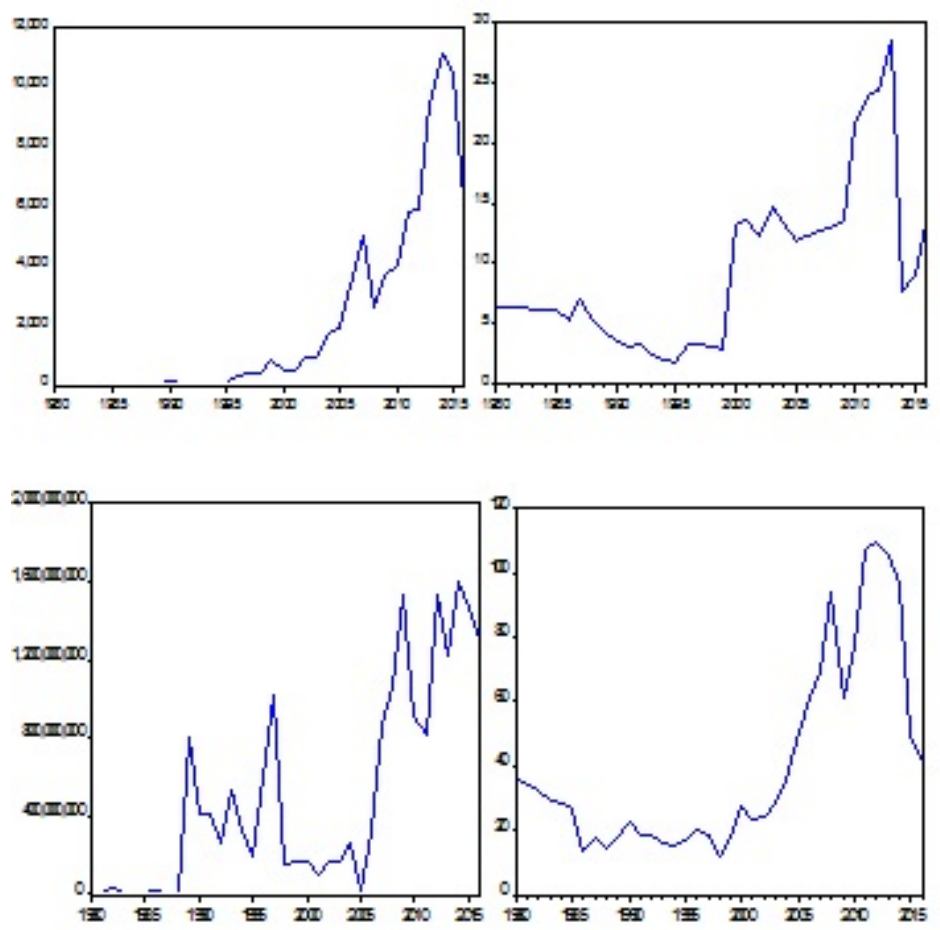

Figure 1. Variables used in this study

4.4. Model. The empirical model is as given in equation (5). Generally, models such equation (5) often referred to as reduced form models are classified as long-run models. The 
coefficients estimates show the magnitude of the effects of the exogenous variables in the longrun. For us to distinguish short-run effects from long-run effects, we transform equation (5) into an error-correction modelling specification given as equation (10):

$$
\begin{aligned}
\triangle \ln U E P_{t}= & \alpha_{0}+\pi_{1} \ln U E P_{t-1}+\pi_{2} \ln O I P_{t-1}+\pi_{3} \ln R G D P_{t-1}+ \\
& +\pi_{4} \ln F D I_{t-1}+\sum_{i=1}^{p-1} \omega_{i} \triangle \ln U E P_{t-i}+\sum_{i=0}^{q} \tau_{i} \triangle \ln O I P_{t-i}+ \\
& +\sum_{i=0}^{q} \vartheta_{i} \triangle \ln R G D P_{t-i}+\sum_{i=0}^{q} \sigma_{i} \triangle \ln F D I_{t-i}+\mu_{t}
\end{aligned}
$$

In the above specification, the difference terms capture the short-run effects of each variable. In selecting the lag length (n), the study uses the Akaike Information Criterion (AIC). We obtain the long-run effects through the estimates of $\pi \mathscr{2}-\pi_{4}$ normalized on $\pi 1$. However, to ensure the validity the long-run estimates, Pesaran et al. (2001) recommend the application of the standard $F$ test to establish the joint significance of lagged level variables in equation (10), which is an indication of cointegration.

As discussed at the beginning of section 4, a key assumption of equation (10) is that changes in any of the independent variables have symmetric effect on the rate of unemployment. However, as noted in few earlier studies (see for example Bocklet and Baek 2017, Cuestas and Gil-Alana 2017), one cannot rule out strong possibility of asymmetric effect of movements in the price of oil on unemployment. To consider this, equation (10) is transformed into non-linear form by introducing partial sum of positive $O I P_{t}^{+}$and negative changes in oil prices $O I P_{t}^{-}$into equation (10) to give:

$$
\begin{aligned}
\triangle \ln U E P_{t}= & \alpha_{o}+\gamma \ln U E P_{t-1}+?_{1}^{+} \ln O I P_{t-1}^{+}+?_{1}^{-} \ln O I P_{t-1}^{-}+8_{1} \ln R G D P_{t-1}+ \\
& +\emptyset_{1} \ln F D I_{t-1}+\sum_{i=1}^{p-1} \partial_{i} \triangle \ln U E P_{t-i}+\sum_{i=0}^{q} d_{1^{\prime} i}^{+} \triangle \ln O I P_{t-i}^{+}+ \\
& +\sum_{i=0}^{q} d_{1^{\prime} i}^{-} \triangle \ln O I P_{t-i}^{-}+\sum_{i=0}^{q} ?_{i} \triangle \ln R G D P_{t-i}+\sum_{i=0}^{q} ?_{i} \triangle \ln F D I_{t-i}+\mu_{t}
\end{aligned}
$$

Equation (11) is referred to as a non-linear ARDL model simply because it incorporates $O I P_{t}^{+}$and $O I P_{t}^{-}$(Shin et al, 2014). Essentially, the condition for movements in oil prices to have symmetric effect is that the estimated coefficients of $O I P_{t}^{+}$and $O I P_{t}^{-}$must be the same in terms size and sign. If this condition does not hold, then their effects are said to be asymmetric.

\section{Results}

Given the fact that the existence of I(2) variables renders bound testing procedure invalid, we check all the variables for stationarity using ADF unit root tests with both intercept and trend.

\begin{tabular}{|c|c|c|c|c|}
\hline \multicolumn{5}{|c|}{ Table 2: ADF Unit root tests } \\
\hline ADF test & \multicolumn{2}{|c|}{ Level } & \multicolumn{2}{c|}{ First Difference } \\
\hline Results & Intercept & Trend & Intercept & Trend \\
\hline $\ln U E P$ & -1.360 & -2.135 & $-4.731^{* * *}$ & $-4.665^{* * * *}$ \\
\hline $\ln O I P$ & -1.174 & -2.104 & $-3.844^{* *}$ & $-3.749^{* *}$ \\
\hline $\ln R G D P$ & -0.778 & $-3.122^{*}$ & $-5.806^{* * *}$ & $-5.702^{* * *}$ \\
\hline $\ln F D I$ & -1.628 & -2.418 & $-5.506^{* * *}$ & $-5.416^{* * *}$ \\
\hline Note: *,** and $* * *$ indicate significance level for $10 \%, 5 \%$ and $1 \%$ respectively. \\
\hline
\end{tabular}


Table 2 presents the results of the unit root tests. The results show that all the variables are stationary when differenced once for both intercept and linear. However, real gross domestic product (RDGP) is stationary at level for trend.

Furthermore, we apply the Zivot-Andrews (1992) unit root. This test allows for one endogenous break in the series. Table 3 presents the results of the Zivot-Andrews (1992) unit root test. The results in table 3 show that three variables, namely unemployment rate, oil price and foreign direct investment turn to break stationary at level while real gross domestic variable turns to break stationary when differenced once.

\begin{tabular}{|c|c|c|c|c|c|c|c|c|c|}
\hline \multicolumn{9}{|c|}{ Table 3: Unit Root with Structural Break } \\
\hline & \multicolumn{7}{|c|}{ Level } & \multicolumn{7}{c|}{ First Difference } \\
\hline Variable & Intercept & B.D & Trend \& & B.D & Intercept & B.D & Trend \& & B.D & Rmk \\
\hline & & & Intercept & & & & Intercept & & \\
\hline $\ln U E P$ & $-4.41^{*}$ & 1999 & $-5.07^{* *}$ & 1999 & $-7.55^{* * *}$ & 2000 & $-7.26^{* * *}$ & 2000 & $\mathrm{I}(0)$ \\
\hline $\ln O I P$ & -3.31 & 2003 & $-3.31^{*}$ & 2003 & $-6.67^{* * *}$ & 2014 & $-7.21^{* * *}$ & 2013 & $\mathrm{I}(0)$ \\
\hline $\ln R G D P$ & -3.21 & 1995 & $-5.42^{* * *}$ & 1995 & $-8.99^{* * *}$ & 1990 & $8.81^{* * *}$ & 1990 & $\mathrm{I}(1)$ \\
\hline $\ln F D I$ & $-5.26^{* * *}$ & 1988 & $-5.46^{* * *}$ & 1988 & $-9.36^{* * *}$ & 1989 & $-9.14^{* * *}$ & 1989 & $1(0)$ \\
\hline \multicolumn{8}{|c|}{ Note:,$^{* *}$ and $*^{* *}$ denote statistical significance at the $10 \%, 5 \%$ and $1 \%$ respectively. } \\
\hline
\end{tabular}

Next, we use the linear ARDL bounds test for cointegration to establish the existence or otherwise of the long-run symmetry in the relationship among the variables. The results of the bounds test for linear and non- linear cointegration F-PSS are as presented in table 4.

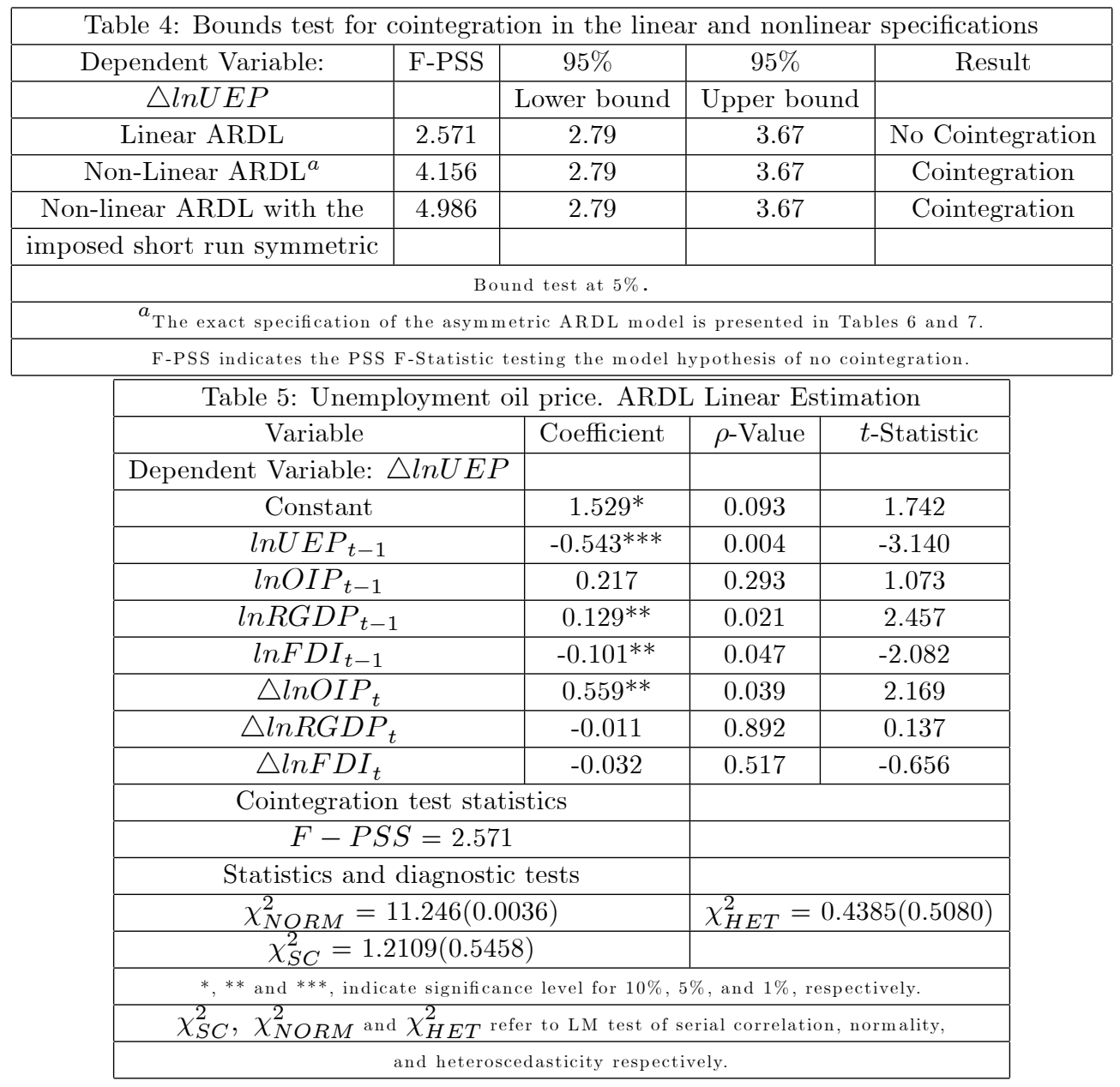


The test indicates the rejection of the alternate hypothesis of cointegration since $F$-PSS $=$ 2.571 for the linear model (Equation 10) lies beneath the lower bound. This finding clearly shows that the variables in the model are not cointegrated. Also presented in table 4 are the results of the cointegration test for NARDL model as presented in equation (11). As shown in table 4, the F-statistic of the NARDL relationship lies above than the upper bound of the critical value (F-PSS $=4.156)$, hence the rejection of the hypothesis of no co-integration. This result shows that the variables in the model, namely unemployment, real gross domestic product, oil price and foreign direct investment are cointegrated. In other word, there is a long-run relationship amongst the variables.

The results presented in table 5 reveal that the coefficient of unemployment rate lagged one year is significant $(\beta=-0.543 ; \rho$-value $=0.004)$. Real income variable has a significantly positive sign in the long run but not in the short run. This finding suggests that improved economic condition in Nigeria has an adverse effect on the rate of unemployment in the long-run. The estimated coefficient of oil price is positive and significant in short-run. Oil price though, has positive effect in the long term; the, coefficient is not significant. This finding means that an increase oil price will lead to an increase in the rate of unemployment in Nigeria, especially in the short-run period. However, as the bounds test confirms no cointegration in the linear model, one cannot draw conclusive inference from the results obtained.

One probable reason for lack of long-run co-movement in the linear ARDL model is the possible non-linear relationship among the variables. In order to verify this possibility, the study employs the NARDL bounds test to examine the possible non-linear relationship. Consequently, the study estimates equation (11) and the results are presented in table 6 . The existence or otherwise of short- and long-run asymmetric impact is verified by the Wald test. The Wald results are contained in the bottom of table 6 .

\begin{tabular}{|c|c|c|c|}
\hline \multicolumn{4}{|c|}{ Table 6: NARDL Estimation Results } \\
\hline Variable & Coefficient & $\rho$-Value & $t$-Statistic \\
\hline \multicolumn{4}{|l|}{ Dependent Variable: $\triangle \ln U E P$} \\
\hline Constant & $4.664 * * *$ & 0.002 & 3.527 \\
\hline $\ln U E P_{t-1}$ & $-0.821^{* * *}$ & 0.0002 & -4.411 \\
\hline $\ln O I P_{t-1}^{+}$ & $0.595^{* * *}$ & 0.013 & 2.728 \\
\hline $\ln O I P_{t-1}^{-}$ & -0.034 & 0.879 & -0.153 \\
\hline $\ln R G D P$ & -0.052 & 0.485 & -0.711 \\
\hline $\ln F D I_{t-1}$ & $-0.218^{* * *}$ & 0.004 & -3.952 \\
\hline$? \ln O I P_{t}^{+}$ & $1.240^{* *}$ & 0.015 & 2.66 \\
\hline$\triangle \ln O I P_{t-2}^{+}$ & 0.634 & 0.146 & 1.508 \\
\hline$\triangle \ln O I P_{t-2}^{+}$ & $1.059^{* *}$ & 0.038 & 2.219 \\
\hline$\triangle \ln F D I_{t}$ & $-0.103^{*}$ & 0.067 & -1.929 \\
\hline$\triangle \ln F D I_{t-1}$ & 0.066 & 0.183 & 1.377 \\
\hline \multicolumn{2}{|c|}{ Long run (LR) asymmetric coefficient } & \multicolumn{2}{|c|}{ Long and short run asymmetric tests } \\
\hline \multicolumn{2}{|l|}{$L R_{\ln O I P}^{+}=0.725^{* * *}$} & \multicolumn{2}{|c|}{$W_{L R, \ln O I P}=4.354^{* *}(0.0493)$} \\
\hline \multicolumn{2}{|l|}{$L R_{\overline{l n} O I P}^{-}=0.04$} & \multicolumn{2}{|c|}{$W_{S R, \ln O I P}=0.188(0.8304)$} \\
\hline \multicolumn{2}{|c|}{ Statistics and diagnostic tests } & \\
\hline \multicolumn{2}{|l|}{$\chi_{S C}^{2}=0.5264(0.5991)$} & \multicolumn{2}{|c|}{$\chi_{H E T}^{2}=2.8453(0.1028)$} \\
\hline \multicolumn{2}{|c|}{$\chi_{N O R M}^{2}=0.9616(0.6182)$} & \multicolumn{2}{|c|}{$\chi_{F F}^{2}=1.560(0.226)$} \\
\hline \multicolumn{4}{|c|}{$*, * *$ and $* * *$ denote significance level for $10 \%, 5 \%$ and $1 \%$ respectively. } \\
\hline \multicolumn{4}{|c|}{ WLR, WSR: Wald test for null of long- and short run symmetry, respectively. } \\
\hline \multicolumn{4}{|c|}{$\chi_{S C}^{2}, \chi_{N O R M}^{2}, \chi_{H E T}^{2}$ and $\chi_{F F}^{2}$ refer to LM test of serial correlation, } \\
\hline 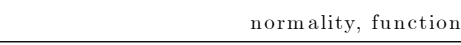 & form and $h$ & cedasticit & spectively. \\
\hline
\end{tabular}

The results reveal the acceptance of the alternative hypothesis in the long run. Specifically, Wald test result is $W_{L R, \operatorname{lnOIP}}=4.354^{* *}(0.0493)$. This result shows that unemployment differently to an upward movement and to a downward movement in oil price. However, the 
results for the short-run indicate the rejection of the alternative hypothesis $\left(W_{S R}\right.$, lnOIP $=$ $0.188(0.8304))$. This finding suggests that in the short-run, increase or decrease in oil price does not have a different impact on unemployment. The implication of this finding is that there is no asymmetric effect of oil price change in the short-run.

Essentially, from the results obtained, the asymmetry in the effects of shocks to oil price on unemployment rate in Nigeria is a long-run rather than short- run phenomena. The basic inference from this finding is that the best way of modelling the interrelationships between the oil price and unemployment is NARDL that allows for short run symmetry with long run asymmetry.

Hence, we re-estimate the equation (11) by allowing only for asymmetries in the long-run with imposed short-run symmetry. Table 7 contains the results obtained from the estimation. The results show that the two main factors that explain long-run equilibrium of unemployment in Nigeria are changes in oil price and foreign direct investment. However, the short-run dynamics of unemployment are described by the lagged value of the foreign direct investment and lagged unemployment rate. The results provide evidence of significant asymmetric effects of oil price shocks in the long-run. The estimated coefficients of negative and positive partial sums decompositions of the oil price $\left(\mathrm{op}^{-}\right.$and $\left.\mathrm{op}^{+}\right)$are negative and positive, respectively. However, only the negative partial sums decomposition of the price of oil $\left(\mathrm{op}^{-}\right)$shows statistical significance at $1 \%$ level.

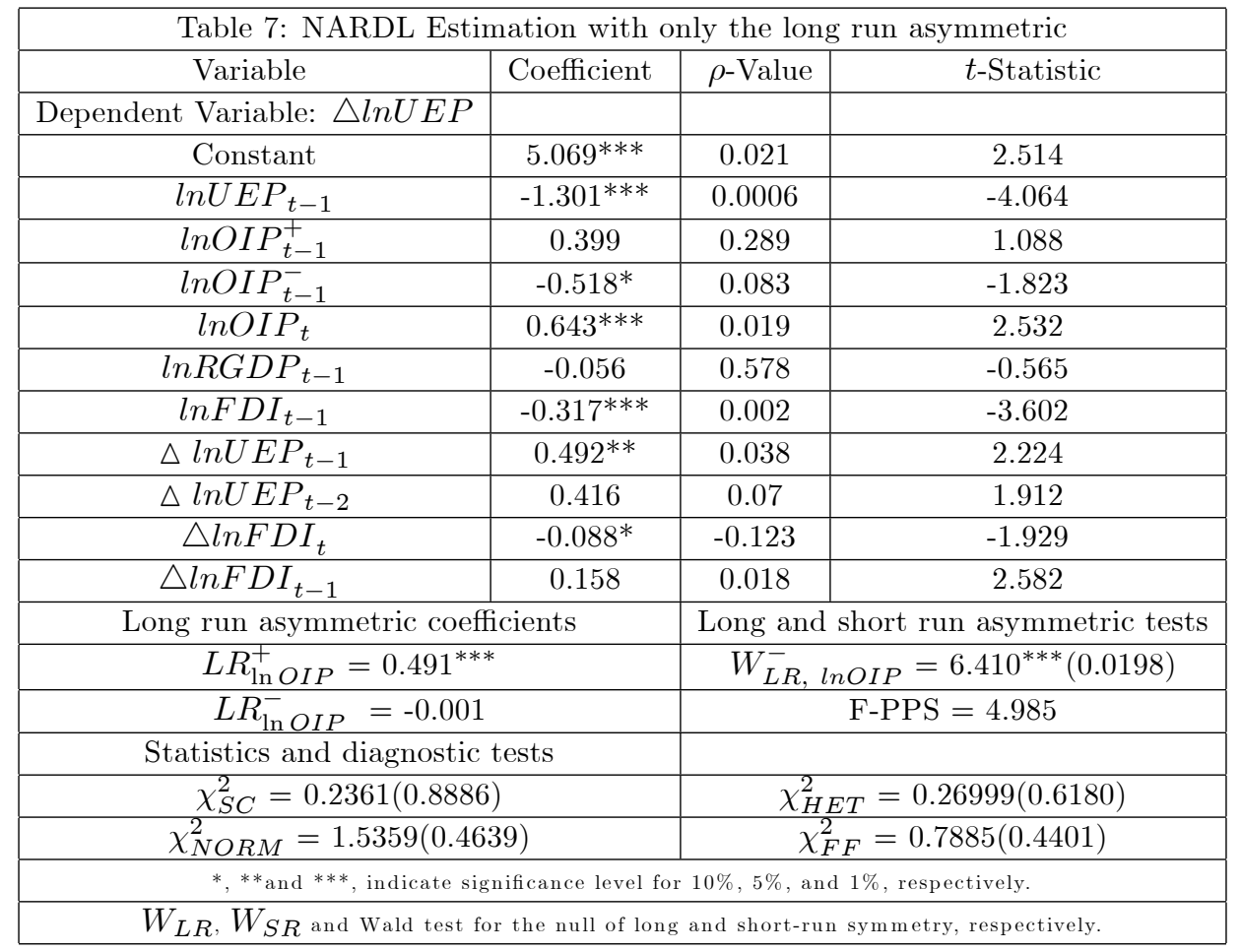

The result shows that the unemployment rate will increase as oil price increases though not significant, while the unemployment rate reduces as oil price falls. As revealed in table 7, foreign direct investment has a beneficial effect of reducing the unemployment rate, particularly in the long-run period. This finding rejects the assertion that inflow of extractive FDI may not generate employment especially in the long run period. The long run coefficients of negative and positive changes of the oil price are -0.001 and 0.491 respectively. This finding simply shows that a 1 per cent decrease in the price of oil leads to an approximately -0.001 per cent decrease in the unemployment rate though not significant. In contrast, a 1 per cent increase in the price of oil precipitates a 0.491 per cent increase in the unemployment rate. This finding seems to contradict a priori expectation. In a country that produces and exports oil, the expectation is 
that an increase in the price of oil would boost revenue with an expected positive impact on output and employment. However, our finding seems to support the peculiar situation of the Nigerian economy. The country is not just a major producer and exporter of crude oil but also a major importer of refined petroleum products. This simply suggests that the expected benefits from the rising price of fuel at the international market are eroded by the massive importation of refined products laden with massive corruption.

The statistics provided at the lower part of table 7 represent the diagnostic evaluation measures for serial correlation LM (x2sc) and the ARCH (x2HET) test for heteroskedasticity. These diagnostic test statistics show that the estimated model is well specified. Moreover, graphs of the cusum and cusumsQ statistics used to ascertain the structural stability of the model, as shown in figures $2 \& 3$ respectively show prevalent of stability. In two cases, the statistics lie within the critical bounds. This finding implies that all the estimated coefficients in the models are stable.

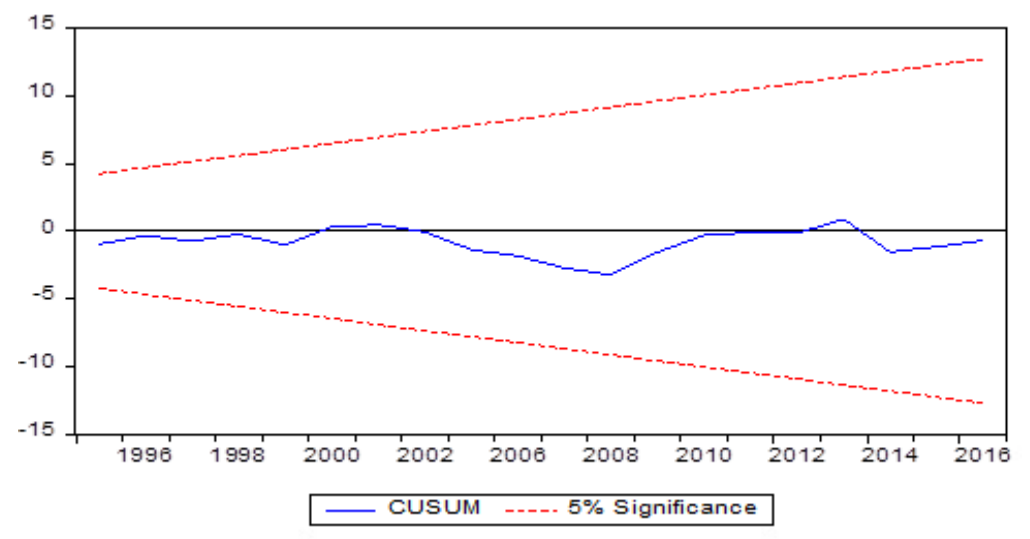

Fig. 2: Plot of cumulative sum based on non-linear distributed lag model estimation

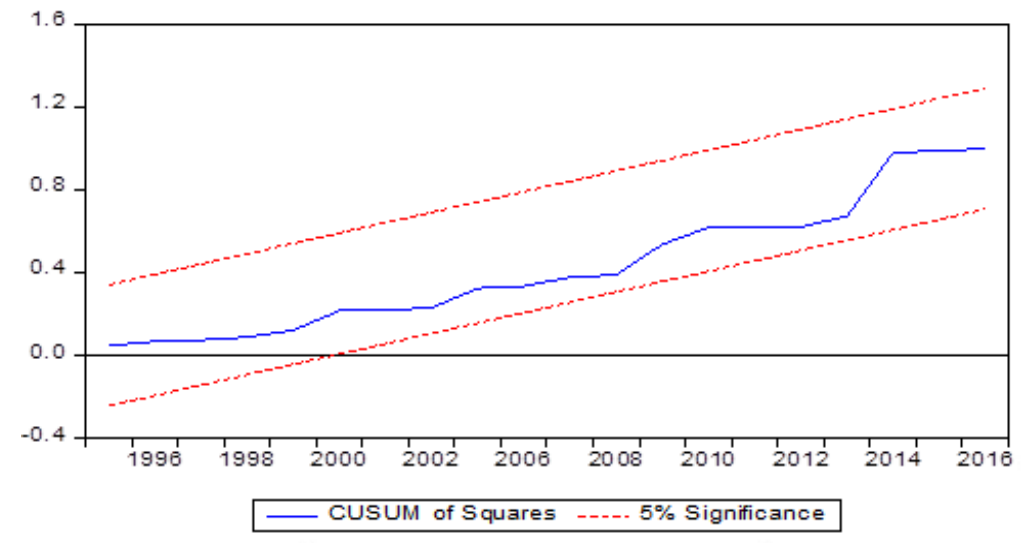

Fig. 3: Plot of cumulative sum of square based on non-linear distributed lag model estimation

\section{Conclusion}

Nigeria is an oil-dependent economy. Oil is a major source of revenue in the country. Indeed, the state derives over 80 per cent of her total revenue from oil. Paradoxically, oil import constitutes a significant component of the import bills of the country. Hence, shocks to the oil price tend to have significant and radiant repercussion on the economy. This study examines the oil price-unemployment rate nexus in Nigeria over the period 1980-2016 using the non-linear autoregressive distributed lag model approach(NARDL) developed by Shin et al. (2014). This approach provides an opportunity for testing the long- and short-run asymmetric response of 
unemployment to the negative and positive partial sums decompositions of the oil price. First, we estimate the linear ARDL model and find no evidence of cointegration in the long run. Consequently, the study examines the non-linear ARDL model.

The estimated non-linear model obtained using the long-run asymmetry with imposed shortrun symmetry came out to be the best way for modelling the dynamic interactions between the oil price shocks and the unemployment rate. The results of the NARDL show that the long-run equilibrium unemployment rate is mostly explained by foreign direct investment and oil price. However, short-run dynamics of the unemployment rate is explained by lagged value of the unemployment rate, and lagged foreign direct investment. Also, the results reveal a significant asymmetric effect of shocks to the oil price in the long-run. The coefficient of negative and positive partial sums decompositions of the oil price $(\mathrm{OP}-$ and $\mathrm{OP}+$ ) are negative and positive, respectively but significant only for oil price reduction. Finally, FDI has a beneficial effect on reducing unemployment, particularly in the long run.

What are the main policy inferences from these finding? The results show that in the long run period employment will be boosted in the country with more foreign direct investment inflows. Government needs to provide enabling environment to attract more foreign investment into the country. Policy measures that help to open up the economy such as removal of restrictions on profits, provision of adequate security and relaxation of restriction on capital remittances will no doubt be useful. Also, an upward movement in the price of oil at the international market can only be beneficial to the country in terms of increased employment if the practice of importing refined petroleum products as against local refining is appropriately resolved by the government. Government efforts in the direction will include the following. Firstly, the current refineries need to be rehabilitated to ensure that they produce at full capacity. However, for this option to work, government must be ready to deal decisively with current high level of corruption in the sub-sector. In the alternative, government might consider the possibility of selling the refineries to private investors to ensure efficiency. Secondly, government needs to liberalise the oil sector to ensure increased private sector participation. Hence, the appropriate regulatory environment and incentives must be provided by the government. In general, the findings of this paper bring to the fore the importance of understanding the asymmetric oil price effects to better address their outcomes on unemployment problem in the country. By implication, there is the need to carefully investigate the sources of oil shocks in order to adopt appropriate policies in the economy. A major area of future research is investigating the effect of oil price changes on sectoral employment. This type of research will assist government in the implementation of right policies to address employment issue in each sector of the economy.

\section{REFERENCES}

[1] Ahmad, F. 2013. The effect of oil prices on unemployment: evidence from Pakistan. Business and Economics Research Journal, 4(1):43-57.

[2] Altay, B., Ebru, E., and Mert, T. 2013. Oil price, output and employment in Turkey: Evidence from vector error correction model. International Journal of Energy Economics and Policy, 3: 7-13.

[3] Andreopolous, S. 2006. The real interest rate, the real oil price, and US Unemployment revisited. Ph.D dissertation at Birkbeck College, University of London, Uk.

[4] Bocklet, J., and Baek, J. 2017. Do oil price changes have symmetric or asymmetric effects on unemployment rate?: Empirical evidence from Alaska. Energy Sources. Part B: Economics, Planning, and Policy 12(1): 1-6.

[5] Brown S. P. A. and Yucel, M. K. 1999. Oil prices and the economy. Southwest Economy 4: 1-6.

[6] Brown, S. P. A. and Yucel, M. K. 2002. Energy prices and aggregate economic activity: An interpretative study. Quarterly Review Economics and Finance 42: 193-208.

[7] Burbidge, J., and Harrison, A. 1984. Testing the effects of oil-price rises using vector autoregressions. International Economic Review, 25(2): 459-484.

[8] Cuestas, J. C., and Gil-Alana, L. 2018. Oil price shocks and unemployment in Central and Eastern Europe. Economic Systems, 42(1): 164-173.

[9] Dogrul, H. G., and Soytas, U. 2010. Relationship between oil prices, interest rate, and unemployment: evidence from an emerging market. Energy Economics 32(6): 1523-1528. 
[10] Dohner, R. S. 1981. Energy prices, economic activity and inflation: survey of issues and results. In: Mork, K. A.(Ed.), Energy Prices, Inflation and Economic Activity. Ballinger, Cambridge, MA.

[11] Ewing, B. T. and Thompson, M. A. 2007. Dynamic cyclical co-movements of oil prices with industrial production, consumer prices, unemployment, and stock prices, Energy Policy 35: 5535-5540.

[12] Garruth, A., Hooker, M., and Oswald, A. 1998. Unemployment equilibria and input prices: theory and evidence from the United States. Review of Economics and Statistics 80: 621-628.

[13] Gisser, M., and Goodwin, T. H. 1986. Crude oil and the macroeconomy: tests of some popular notions. Journal of Money Credit and Banking 18(1): 95-103.

[14] Gunu, U., and Kilishi, A. A. 2010. Oil price shocks and the Nigerian economy: a variance autoregressive (VAR) model. International Journal of Business and Management 5(8): 39-49.

[15] Hamilton, J. D. 1983. Oil and the macro economy since World War 11. Journal of Political Economy, 91: 228-248.

[16] Hamilton, J. D. 1988. A neoclassical model of unemployment and the business cycle. Journal of Political Economy 96(3): 593-617.

[17] Kisswani, A. M. and Kisswani K. M. 2019. Modelling the employment-oil price nexus: a non-linear cointegration analysis for the U. S. market. Journal of International Trade \& Economic Development, 1-17.

[18] Kocaarslan B., Soytas, M. A., and Soytas U. 2019. The asymmetric impact of oil prices, interest rates and oil price uncertainty on unemployment in US. SSRN Electronic Journal, 1-32.

[19] Lee, K., Ni, S., and Ratti, R. A. 1995. Oil shock and the macroeconomy: the role of price variability. Energy Journal 16(4): 39-56.

[20] Lescaroux, F., and Mignon, V. 2008. On the influence of oil prices on economic activity and other nacroeconomic and financial variables, OPEC Energy Review 32 (4): 343-380.

[21] Loschel, A., and Oberndorfer, U. 2009. Oil and unemployment in Germany. ZEW Discussion Papers, No. $08-136$.

[22] Loungani, P. 1986. Oil price shocks and dispersion hypothesis. The Review of Economics and Statistics 68 (3): 536-539.

[23] Michieka, N. and Gearhart, R. 2015. Oil price fluctuations and employment in Kern country: a vector error-correction approach. Energy Policy 87: 584-590.

[24] Moller, N. F. 2013. Understanding unemployment hysteresis: a system-based econometric approach to changing equilibria and slow adjustment. Discussion Papers 13-06, University of Copenhagen, Department of Economics.

[25] Moller, N. F. 2017. How to decode unemployment persistence: an econometric framework for identifying and comparing the sources of persistence. Munich Personal RePEc Archive Paper No. 70058

[26] Monk, K. A. 1994. Business cycles and the oil market. Energy Journal 15: 15-38.

[27] Mory, J. F. 1993. Oil prices and economic activity: is the relationship symmetric? The Energy Journal 14(4): 151-161.

[28] Papapetrou, E. (2001). Oil price shocks, stock market, economic activity and employment in Greece. Energy Economics 23: 511-532.

[29] Pesaran, M. H., Shin, Y., and Smith, R. J. 2001. Bounds testing approaches to the analysis of level relationships. Journal of Applied Econometrics, 16: 289-326.

[30] Rafiq, S., Salim, R. and Bloch, H. 2009. Impact of crude oil price volatility on economic activities: an empirical investigation in the Thai economy. Resources Policy 34: 121-132.

[31] Ran, J. and Voon, J. P. 2012. Does oil price shock affect small open economy? evidence from Hong Kong, Singapore, South Korea and Taiwan. Applied Economics Letters 19(16): 1599-1602.

[32] Robalo, P. B. and Salvado, J. C. 2008. Oil price shocks and the Portuguese economy since 1970s. FEUNL Working Paper series no. 529.

[33] Schmidt, E. and Zimmermann, T. 2007. Why are the effects of recent oil price shocks so small? RUHR Economic Paper No. 21.

[34] Schmidt, T., and Zimmermann, T. 2005. Effects of oil price shocks on German business cycles. RWI Discussion Papers No. 31

[35] Senzangakhona, P., and Choga, I. 2015. Crude oil prices and unemployment in South Africa: 1990-2010. Mediterranean. Journal of Social Sciences. 6(2): 407-414.

[36] Shapiro, C., and Stiglitz, J. E. 1984. Equilibrium unemployment as a worker discipline device. American Economic Review 74(3): 433-444.

[37] Shin, Y., Yu, C., and Greenwood-Nimmo. 2014. Modelling asymmetric cointegration and dynamic multipliers in a nonlinear ARDL framework. In Festschrift in Honor of Peter Schmidt, edited by W. C. Horrace and R. C. Sickles. New York (NY): Springer Science \& Business Media.

[38] Uri, N. D., 1996. Crude oil price volatility and unemployment in the United States. Energy 21(1): 29-38.

[39] Zivot, E., and Andrews, D. W. K. 1992. Further evidence in the great crash, the oil-price shock, and the unit root hypothesis. Journal of Business and Economic Statistics. 10: 251-270. 